\title{
PLAYA DE ESCOMBROS
}

(FRAGMENTO)

\section{Lucas Costa (2010)}

Una alfombra de espuma

entre los poros del mar.

En esa baba se asoman

chocando los vestigios

y apretados se atisban:

apaleado un refri

sirve ahora de recipiente

para el descargo de la sal,

un juego de niños desparramado

sin caja ni instructivos, una peineta de dientes careados se exhibe como única sonrisa haciendo la pega del sarcasmo al costado de una cáscara de lo que fuera una morsa o algo así a la deriva. Una muñeca parpadea por un ojo El restante lo mastica una gaviota haciéndose cargo de desmalezar los signos del caos: bajo el reflujo se asoma la playa como huellas de una casa hecha de pistas.

Lo primero en descomponerse es el cuerpo humano, el mar no lo devuelve todo cuando la sal se encarga de corroerlo en un pestañar, hacerlo uno con el agua que se amaina en dar tumbos e incluso el conteo regresivo se hace incoherente y las piezas se las tiene que ingeniar uno para volver a recomponer, para armar los pedazos de por aquí, por allá cada quién con su letra y número en mano a la espera de un amague sigiloso de la arena en retirada. 